\title{
Foundations for Effective Sustainability Education
}

Authors Lynne Eagle, David R Low, Lisa Vandommele, Siqiwen Li

School of Business, James Cook University, Townsville QLD 4811 Australia, Phone (0061) 74781 5717, Fax (07) 4781 5717, Email: lynne.eagle@jcu.edu.au; david.low@jcu.edu.au, lisa.vandommele@jcu.edu.au, siqiwen.li@jcu.edu.au

\begin{abstract}
This paper presents a two-part study of undergraduate university students regarding attitudes and beliefs regarding climate change adaptation and actual sustainability-related behaviours. The findings reflect naïve awareness of the impact of individual contributions to sustainability and environmental challenges by respondents and a tendency to regard major issues as both beyond personal control and being the responsibility of others. This is coupled with reluctance to consider major lifestyle changes. Contrary to expectations based on extant literature, we find few significant differences in actual sustainability-related behaviours between new entrants and senior students. More concerning is a significant reduction in acceptance of the need to change behaviours and an increase in skepticism regarding the reality of climate change among the latter. A factor analysis shows that common themes identified in the literature fail to reflect the diverse range of influences on young people, including family, friends and news media. Achieving significant long-term changes in behaviours will be a substantial challenge for tertiary curricula when these other influences do not support the curricula themes.
\end{abstract}

Keywords: business students, higher education, sustainability, climate change, environment, attitudes, and behaviour change

\section{Track: 05 Marketing Education}




\section{Introduction}

Universities are increasingly recognized as having a role as change agents in addressing longstanding problems of indifference and inaction regarding climate change impact, environmental protection and sustainability (de la Harpe and Thomas, 2009). This paper reports on one phase of a longitudinal research project examining the effects of a revised undergraduate business studies curriculum. Data from this phase of the project relates to a baseline 'control' group (studying the old curriculum) with whom it was intended to establish benchmarks regarding current knowledge, attitudes, perceived norms and the perceived personal relevance of sustainability issues among incoming students. This paper details the findings regarding the attitudes and beliefs towards sustainability of the control group. Future impacts of the revised curriculum will be assessed against these benchmark measures. Successful strategies for embedding sustainability content into curricula appear to be grounded in a clear understanding of the knowledge and attitudinal base from which students start studying the themes and how studies change their knowledge, attitudes and beliefs over time (Buissink-Smith et al., 2011). However these studies have not tracked long-term effects, and there is European evidence indicating that a sustainability orientation may not be reflected in actual behaviours once students enter the workplace and "vanishes with business experience" (Kuckertz \& Wagner, 2010: 524); the fact that education alone will not change behaviours was signaled as far back as 1990 (Hungerford \& Volk, 1990); knowledge will not be used unless real benefits are perceived (Lourenço et al., 2012. This area is un-researched and requires further investigation.

\section{Literature Review}

The theory of generational replacement (Wray-Lake et al, 2010) suggests that changes in adolescent attitudes are indicators of long term social change, thus if changes are evident in attitudes of students as they progress through their studies, this may indicate the prospect of changes within society as a whole. The extant literature has found that students "undergo profound changes in epistemological assumptions and in identity during their undergraduate years" (Myers \& Beringer, 2010: 51), thus changes in knowledge, attitudes and behaviours regarding sustainability and related issues are possible as students progress through their studies. The nature of these changes has not been studied within the business studies context. The findings reported here indicate that achieving significant long-term changes in behaviours will be a substantial challenge for the revised curriculum.

\section{Competing Forces}

Any behaviour change messages embedded in the curriculum will be subject to a range of competing messages and social encouragement or discouragement through peer and family influences as well as perceived and actual behavioural norms (Peattie \& Peattie, 2003). Families, through socialization and influence are known to impact the environmentallyrelevant behaviours of adolescents (Grønhøj \& Thøgersen, 2012), but the magnitude or duration of this influence is unknown as research has been concentrated on under-18 year olds living at home (Grønhøj \& Thøgersen, 2009).

Media coverage of issues presents several additional challenges. This is because, in the battle for acceptance and legitimacy of mitigation and adaptation messages, counter messages are distributed by interest groups who are promoting 'climate change skepticism' (Antilla, 2005). These messages, communicated largely through the mass media, have been found to be influential in developing public attitudes on these issues (Boykoff and Boykoff, 2004). There is evidence that the media can negatively impact climate change communication by giving equal time to climate change warnings and competing / dissenting views in the interests of 
journalistic fairness. Such 'even handedness', commonplace in the media (Moser \& Dilling, 2004), serves to reinforce perceptions of uncertainty and generates confusion (Boykoff \& Boykoff, 2004). Antilla (2005) suggests that emphasizing controversies may be a deliberate strategy to create drama and interest. Thus the media's impact is not always in line with consensus expert opinion and thus, arguably, not uniformly acting in the public interest. This has been a particular issue in the geographic area in which the author's university is located. Local news media coverage of scientific studies of climate change impact on the environment, particularly the Great Barrier Reef frequently conclude with a well-known climate change "denier" who states that the studies are wrong, for example:

"...there is widespread but erroneous belief in our society that dangerous global warming is occurring and that it has human causation”. (Carter, 2011).

Further, Systems Justification Theory suggests that people will strive to maintain a sense of certainty and stability but that in order to maintain the status quo, may fail to accept risks or to acknowledge personal responsibility for contributions to problems (Feygina et al., 2010). There is a disconnect between perceptions of individual actions and global issues (Threadgold, 2012). Further, altering attitudes and beliefs has been shown to have little impact on willingness to act (Boyes \& Stanisstreet, 2012); the gap between reported attitudes towards environmental issues and actual behaviours is well documented in the literature (Ockwell et al., 2009; Lorenzoni et al., 2007, Sheppard, 2005).

Perceived norms have long been recognized as impacting on behavioural decisions (Cialdini, 2003). Recent developments in the study of normative influence have re-categorized norms into 'injunctive' (what is perceived as being approved or disapproved) and 'descriptive' (what appears to be actually occurring) components (Hennessy, 2010). Interventions that stress descriptive norms may not be effective if they reinforce the belief that challenges are too big for individual actions to have any impact on resolving them (Cialdini, 2007; Semenza et al., 2008). The weakness of simply providing information in anticipation of it leading to behaviour change is acknowledged in the extant literature; as are the inadequacies of many current theories in capturing and charting the interaction of these factors across different population groups (Lorenzoni et al., 2007).

\section{Research Objectives}

The aim of this research was to provide a comparative benchmark measure of new incoming undergraduate students' and senior undergraduate students knowledge of, and attitudes towards, a range of sustainability issues and thus inform the development of the revised curriculum for the Bachelor of Business programs. This then would provide a benchmark where we could examine the knowledge and attitudes towards sustainability issues when first year students had completed their studies providing an impact measurement for the curriculum change.

\section{Methodology}

Questions were derived from common themes in the literature and previously used instruments, including: Michalos et al. (2011), Shephard et al. (2009); Kagawa (2007); Lidgren et al. (2006); Marcell et al., (2004) and Kaplowitz \& Levine (2005). Familiarity with key terms was tested, followed by 34 statements covering a range of knowledge, attitudes, behaviours and normative influences, perceived self-efficacy, and optimism versus pessimism regarding the future. Good internal consistency was evident $(\alpha=.89)$. For the statements, a five-point Likert scale was used, with anchor points of $5=$ strongly agree and 1 $=$ strongly disagree. A 6th option of don't know / not interested was included. This latter 
option was intended to provide an alternative for those who have only vague understandings or no true opinion on the statements listed (Sturgis \& Smith, 2010; Krosnick et al., 2002) rather than forcing an artificial pseudo-opinion (Malone et al., 2010). The questionnaire was run with new incoming year one students and with final year students in their final semester of study. The profile of respondents was as follows: Year 1: $n=167$; Year 3: $n-80$; Males $=34 \%$, Females $66 \%$.

\section{Analysis and Discussion}

The data reflects naïve awareness in both groups of the impact of individual contributions to sustainability and environmental challenges. They reveal a tendency to regard major issues as beyond personal control and to view solutions as being the responsibility of others. This is coupled with reluctance to consider major lifestyle changes in order to adapt to climate change challenges. While the literature indicates that changes in perceptions between new entrants and senior students could be expected, there were few significant differences. In terms of self-reported knowledge of the key terms, Third-year students appear to have significantly higher levels of knowledge of four of the terms, i.e. economic sustainability, sustainable development, conservation, climate change and environmental protection but a significantly lower level of knowledge about climate change adaptation than first year students.

We found no significant difference between the two cohorts in self-reported knowledge of climate change causes, current behaviours, personal interest and perceived norms regarding environmental issues and beliefs regarding family, friends and peers and climate change. Responses to only two of the statements regarding responsibility for action showed significant differences between cohorts. However, there was a significantly higher level of agreement for the third year cohort compared to first year students with the statement that overuse of natural resources is a serious threat $(\mathrm{p}=.04)$, but a significantly lower level of agreement with the statement that a radical change to ways of living is needed to offset climate change $\mathrm{p}=.006$ ). There was also a higher level of scepticism among level 3 students about whether climate change was a reality as shown by the following indicative comment: "Why do people make such a deal about it being our fault; the environment changes regardless".

Given that there were few differences between the two cohorts, a factor analysis using principal component analysis and varixmax rotation (Rietveld \& Van Hout, 1993; Field, 2000) was then conducted. The parallel analysis indicates to accept three components, as their actual Principal Component Analysis (PCA) loadings are greater than the simulated ones using Monte Carlo method. A number of items loaded onto multiple factors are deleted based on Cronback's Alpha reliability test (the items with alpha numbers greater than the sample alpha) which 16 items interpreted in table 2 are kept To avoid over-specification and improve the distinction between factors, a minimum component loading of .30 was set. We therefore first assess the suitability of our survey data for exploratory factor analysis. The Kaiser-Meyer-Olkin (KMO) measure shows the sampling adequacy with KMO value of .786 and approximate Chi-Square of 1008.414.The Bartlett's test of Sphericity is also significant with $\mathrm{p}=.000$. Three factors were identified, these being 'Aware but inactive', 'Sustainability active' and 'Skeptical external focus' (Tables 1 and 2). Together, these factors explain 48\% of variance. We suggest that this may be due to the fact that none of the themes identified in the literature included competing and conflicting influences. We therefore included a range of questions relating to perceived trustworthiness of the media used. 
Table 1: Total Variance explained by factors

\begin{tabular}{|l|c|c|c|c|c|c|c|c|c|}
\hline \multirow{2}{*}{$\begin{array}{l}\text { Comp- } \\
\text { onent }\end{array}$} & \multicolumn{3}{|c|}{ Initial Eigenvalues } & \multicolumn{3}{c|}{$\begin{array}{c}\text { Extraction Sums of } \\
\text { Squared Loadings }\end{array}$} & \multicolumn{3}{c|}{$\begin{array}{c}\text { Rotation Sums of Squared } \\
\text { Loadings }\end{array}$} \\
\cline { 2 - 11 } & Total & $\begin{array}{c}\% \text { of } \\
\text { Variance }\end{array}$ & $\begin{array}{c}\text { Cumulati } \\
\text { ve \% }\end{array}$ & Total & $\begin{array}{c}\% \text { of } \\
\text { Variance }\end{array}$ & $\begin{array}{c}\text { Cumulati } \\
\text { ve \% }\end{array}$ & Total & $\begin{array}{c}\% \text { of } \\
\text { Variance }\end{array}$ & $\begin{array}{c}\text { Cumulati } \\
\text { ve \% }\end{array}$ \\
\hline 1 & 4.038 & 25.237 & 25.237 & 4.038 & 25.237 & 25.237 & 3.261 & 20.382 & 20.382 \\
\hline 2 & 1.918 & 11.990 & 37.228 & 1.918 & 11.990 & 37.228 & 2.545 & 15.904 & 36.286 \\
\hline 3 & 1.716 & 10.726 & 47.954 & 1.716 & 10.726 & 47.954 & 1.867 & 11.668 & 47.954 \\
\hline
\end{tabular}

Table 3 shows the ranking of information sources by level of trust. The low level of trust in advertising sources is unsurprising, a 1994 review of six decades of research in this area showed a consistent level of some $30 \%$ of people trusting advertising as a source (Calfee $\&$ Ringold, 1994). The high level of trust in television news is interesting, given that this medium has provided considerable coverage of climate skeptics as part of the 'even handedness' philosophy noted earlier (Low \& Eagle, 2013). The impact of this was evident in small but significant negative co-relations between both Television News $(-.129, p=.042)$ and Television Advertising $(-.154, \mathrm{p}=.016)$ for the statement "I walk or bike to places instead of going by car". We suggest that this may be due to several influences: media coverage and advertising has centered on the benefits of fuel efficient vehicles, with a dearth of positive advertising towards alternatives such as walking or cycling. News coverage of cyclists involved in road accidents is also frequent. A further influence may be that the study took place in a tropical environment where for several months of the year, high heat and humidity makes cycling unattractive. Small but significant negative correlations were also evident regarding the statement "We must set aside areas to protect endangered species" and the trustworthiness of both social media $(-.178 \mathrm{p}=.005)$ and family and friends $(-.123, \mathrm{p}=$ $.05)$. We suggest that this may be due to the location of the campus in an area surrounded by national parks, and the timing of the survey which occurred during a period when the announcement of the Coral Sea Marine Reserve was announced, with acknowledgement of negative impacts on the commercial fishing sector (Australian Government, 2012 / 2013); impacts that were then duly reported in the media.

Table 2 Rotated Component Matrix ${ }^{a}$

\begin{tabular}{|l|r|r|r|}
\hline Statements & $\begin{array}{l}\text { Sceptical } \\
\text { external } \\
\text { focus }\end{array}$ & $\begin{array}{l}\text { Aware but } \\
\text { inactive }\end{array}$ & $\begin{array}{l}\text { Sustain- } \\
\text { ability } \\
\text { active }\end{array}$ \\
\hline Human induced climate change is occurring at some level & & .765 & \\
\hline $\begin{array}{l}\text { The greenhouse effect is caused by an ozone hole in the } \\
\text { earth's atmosphere }\end{array}$ & .731 & .785 & \\
\hline Humankind will die out if we don't live in tune with nature & & .782 & \\
\hline $\begin{array}{l}\text { Every time we use coal, oil or gas we contribute to climate } \\
\text { change }\end{array}$ & & .708 & \\
\hline My personal computer use contributes to climate change & & & .530 \\
\hline I always switch the light off when I don't need it. & & .668 \\
\hline At home I try to recycle as much as I can & & & .680 \\
\hline I have changed to environmentally friendly light bulbs & & & .630 \\
\hline We must set aside areas to protect endangered species & & & .641 \\
\hline $\begin{array}{l}\text { Sustainability is important to me in making choices about } \\
\text { which products or services I choose }\end{array}$ & & & \\
\hline
\end{tabular}




\begin{tabular}{|l|l|l|l|}
\hline $\begin{array}{l}\text { I avoid buying from a company which shows no concern for } \\
\text { the environment }\end{array}$ & & & .578 \\
\hline $\begin{array}{l}\text { Worrying about the environment often holds up } \\
\text { development projects }\end{array}$ & .575 & & \\
\hline Nature is always able to restore itself & .713 & & \\
\hline $\begin{array}{l}\text { Society will contribute to solve even the biggest } \\
\text { environmental problems }\end{array}$ & .645 & & \\
\hline $\begin{array}{l}\text { My friends and family believe they should alter their } \\
\text { behaviour to prevent global climate change }\end{array}$ & .397 & & \\
\hline $\begin{array}{l}\text { There is little action that I can take to reduce the threat of } \\
\text { climate change }\end{array}$ & .593 & & \\
\hline
\end{tabular}

Table 4: Information Sources Ranked by Trust

\begin{tabular}{|l|l|l|}
\hline & High Freq Use \% & High Trust \% \\
\hline Television News & 68.3 & 49.8 \\
\hline Family & 61.7 & 35.2 \\
\hline Friends & 26.5 & 34 \\
\hline Television Advertising & 60.2 & 30.4 \\
\hline Internet & 64.2 & 29.6 \\
\hline Television Documentaries & 36.9 & 27.6 \\
\hline Magazine Advertising & 20.6 & 25.6 \\
\hline Radio News Items & 54.6 & 25.1 \\
\hline Word of Mouth & 70.2 & 23.7 \\
\hline Social Media & 38.6 & 21.1 \\
\hline Radio Advertising & 48.2 & 20 \\
\hline Magazine Editorial & 27.9 & 18.2 \\
\hline Cinema & 54.9 & 16.9 \\
\hline
\end{tabular}

\section{Conclusions and Directions for Future Research}

Academic-originated knowledge provision alone is not likely to overcome climate change skepticism, particularly if this skepticism is reinforced outside the classroom. There is a need for salience, legitimacy and credibility to also be considered in communicating realworld sustainability challenges. Amotivated people cannot see the link between their behaviour and its outcomes, therefore do not see the point of taking action (Cooke \& Fielding, 2009). There is a clear need to investigate barriers to, and potential enablers of behaviour change and the most effective message types, communicators and communications channels that will make sustainability issues personally relevant in terms of immediacy and significance of local impacts. Our future research will examine how the attitudes and perceptions of our students change with the new, sustainably aware, business curriculum foundation and will make recommendations for future curriculum design as well as providing a basis of informed techniques for community based education, aimed at influencing attitudes and behavior, to draw from.

\section{References}

Antilla, L. (2005) "Climate of Scepticism: US Newspaper Coverage of the Science of Climate Change," Global Environmental Change 15(4), 338-352.

Bellamy, R., \& Hulme, M. (2011). Beyond the Tipping Point: Understanding Perceptions of Abrupt Climate Change and Their Implications. Weather, Climate, and Society, 3(1), 48-60. 
Australian Government (2012 / 2013) Coral Sea Marine Reserve. Accessed from: http://www.environment.gov.au/marinereserves/coralsea/index.html

Boykoff, M. T., \& Boykoff, J. M. (2004) "Balance as Bias: Global Warming and the US Prestige Press," Global Environmental Change 14(2), 125-136.

Boyes, E., \& Stanisstreet, M. (2012). Environmental Education for Behaviour Change:

Which actions should be targeted? International Journal of Science Education, 34(10), 15911614.

Calfee, J. E., \& Ringold, D. J. (1994). The 70\% Majority: Enduring Consumer Beliefs About Advertising. Journal of Public Policy \& Marketing, 13(2), 228 - 238.

Carter, R. (2011) "The Futile Quest for Climate Control” Retrieved from http://www.quadrant.org.au/magazine/issue/2008/451/the-futile-quest-for-climate-control Cialdini, R. (2007). Descriptive Social Norms as Underappreciated Sources of Social Control. Psychometrika, 72(2), 263-268.

Cialdini, R. B. (2003). Crafting Normative Messages to Protect the Environment. Current Directions in Psychological Science, 12(4), 105-109.

De la Harpe, B., \& Thomas, I. (2009). Curriculum Change in Universities. Journal of Education for Sustainable Development, 3(1), 75-85

Feygina, I., Jost, J. T., \& Goldsmith, R. E. (2010). System justification, the denial of global warming, and the possibility of "System-Sanctioned Change". Personality and Social Psychology Bulletin, 36(3), 326-338.

Field, A. (2000), Discovering Statistics using SPSS for windows, London, Sage Publications Grønhøj, A., \& Thøgersen, J. (2012). Action speaks louder than words: The effect of personal attitudes and family norms on adolescents' pro-environmental behaviour. Journal of Economic Psychology, 33(1), 292-302

Grønhøj, A., \& Thøgersen, J. (2009). Like father, like son? Intergenerational transmission of values, attitudes, and behaviours in the environmental domain. Journal of Environmental Psychology, 29(4), 414-421.

Hennessy, M., Bleakley, A., Fishbein, M., Brown, L., DiClemente, R., Romer, D., et al. (2010) "Differentiating Between Precursor and Control Variables When Analyzing Reasoned Action Theories," AIDS and Behavior 14(1), 225-236.

Hungerford, H. R., \& Volk, T. L. (1990). Changing Learner Behaviour Through

Environmental Education. Journal of Environmental Education, 21(3), 8-21.

Kuckertz, A., \& Wagner, M. (2010). The influence of sustainability orientation on entrepreneurial intentions - Investigating the role of business experience. Journal of Business Venturing, 25(5), 524-539.

Lidgren, A., Rodhe, H., \& Huisingh, D. (2006). A systemic approach to incorporate sustainability into university courses and curricula. Journal of Cleaner Production, 14(9-11), 797-809.

Lorenzoni, I., Nicholson-Cole, S., \& Whitmarsh, L. (2007) "Barriers Perceived to Engaging with Climate Change Among the UK Public and their Policy Implications," Global Environmental Change 17(3-4): 445-459.

Lourenço, F., Jones, O., \& Jayawarna, D. (2012). Promoting sustainable development : The role of entrepreneurship education. International Small Business Journal, online edition 24 April.

Low, D.R. \& Eagle, L.C. (2013). Climate Change Science versus Climate Sceptics: Is the World Really Flat? Paper in proceedings of the Academy of Marketing Science conference, Brisbane.

Malone, E. L., Dooley, J. J., \& Bradbury, J. A. (2010). Moving from misinformation derived from public attitude surveys on carbon dioxide capture and storage towards realistic stakeholder involvement. International Journal of Greenhouse Gas Control, 4(2), 419-425. 
Marcell, K., Agyeman, J., \& Rappaport, A. (2004). Cooling the campus: Experiences from a pilot study to reduce electricity use at Tufts University, USA, using social marketing methods. International Journal of Sustainability in Higher Education, 5(2), 169-189

Moser, S. C., \& Dilling, L. (2004). Making Climate HOT. Environment: Science and Policy for Sustainable Development, 46(10), 32-46.

Myers, O. E., \& Beringer, A. (2010). Sustainability in Higher Education: Psychological Research for Effective Pedagogy. Canadian Journal of Higher Education, 40(2), 51 - 77. Ockwell, D., Whitmarsh, L., \& O'Neill, S. (2009) "Reorienting Climate Change Communication for Effective Mitigation," Science Communication 30(3), 305-327. Peattie, K., \& Peattie, S. (2003). Ready to Fly Solo? Reducing Social Marketing's Dependence on Commercial Marketing Theory. Marketing Theory, 3(3), 365 - 385. Rietveld, T.\& Van Hout, R., (1993), Statistical Techniques for the Study of Language and Language Behaviour, Berlin, Mouton DE Gruyter

Semenza, J. C., Hall, D. E., Wilson, D. J., Bontempo, B. D., Sailor, D. J., \& George, L. A. (2008). Public Perception of Climate Change: Voluntary Mitigation and Barriers to Behavior Change. American Journal of Preventive Medicine, 35(5), 479-487.

Sheppard, S. R. J. (2005) "Landscape Visualisation and Climate Change: the Potential for Influencing Perceptions and Behaviour," Environmental Science \& Policy 8(6): 637-654. Sturgis, P., \& Smith, P. (2010). Fictitious Issues Revisited: Political Interest, Knowledge and the Generation of Nonattitudes. Political Studies, 58(1), 66-84

Threadgold, S. (2012). 'I reckon my life will be easy, but my kids will be buggered': ambivalence in young people's positive perceptions of individual futures and their visions of environmental collapse. Journal of youth studies, 15(1), 17-32.

Wray-Lake, L., Flanagan, C. A., \& Osgood, D. W. (2010). Examining Trends in Adolescent Environmental Attitudes, Beliefs, and Behaviors Across Three Decades. Environment and Behavior, 42(1), 61-85. 